\title{
KESESUAIAN LAHAN DAN REVITALISASI TAMBAK BUDIDAYA UDANG DI KAWASAN INDUSTRIALISASI KABUPATEN PROBOLINGGO PROVINSI JAWA TIMUR
}

\author{
Utojo, Arifuddin Tompo, dan Rezki Antoni Suhaimi \\ Balai Penelitian dan Pengembangan Budidaya Air Payau \\ Jl. Makmur Dg Sitakka No. 129, Maros 90512, Sulawesi Selatan \\ E-mail: utojorivai@gmail.com
}

(Naskah diterima: 2 April 2014; Revisi final: 13 Oktober 2014;

Disetujui publikasi: 10 November 2014)

\begin{abstract}
ABSTRAK
Penelitian ini bertujuan untuk menentukan kesesuaian lahan tambak budidaya udang di kawasan industrialisasi Kabupaten Probolinggo, Jawa Timur dan mengkaji strategi revitalisasi tambak berdasarkan hasil penelitian remediasi kualitas tanah dan air tambak. Data primer meliputi: topografi, lahan, dan hidrologi pesisir diperoleh melalui survai lapangan. Penentuan stasiun pengamatan dilakukan secara acak dan sistematik. Setiap lokasi pengambilan contoh ditentukan posisi koordinatnya dengan alat Global Positioning System (GPS). Data sekunder yang digunakan berupa data iklim, peta Rupa Bumi Indonesia kawasan Probolinggo skala 1:25.000 dan citra satelit ALOS AVNIR-2 tahun 2010. Data lapangan (topografi, pasang surut, fisika-kimia air dan tanah), data citra satelit ALOS AVNIR-2 dan data sekunder yang lain, dianalisis secara spasial menggunakan Sistem Informasi Geografi (SIG) untuk memperoleh tingkat kesesuaian lahan. Berdasarkan hasil analisis kesesuaian lahan tambak dari total luasan tambak 2.143 ha, lahan yang sangat sesuai dan sesuai untuk budidaya udang yaitu 56 ha dan 618 ha. Lahan tersebut tersebar di Kecamatan Tongas dan Pajarakan. Lahan yang cukup sesuai ditemukan sebesar 1.235 ha, dan tersebar di Kecamatan Tongas, Sumberasih, Dringu, Gending, Kraksaan, Pajarakan, dan Paiton. Sedangkan lahan yang tidak sesuai yaitu 234 ha, terdapat di Kecamatan Sumberasih, Gending, dan Kraksaan. Percepatan target peningkatan produksi di tambak budidaya udang kawasan industrialisasi dapat dicapai melalui kesesuaian lahan dan revitalisasi tambak (perbaikan kualitas tanah dan air).
\end{abstract}

KATA KUNCl: tambak, budidaya udang, kesesuaian lahan dan revitalisasi, Kabupaten Probolinggo

ABSTRACT: Land suitability and revitalization of brackishwater pond for shrimp culture in industrialization area of Probolinggo Regency East Java Province. By: Utojo, Arifuddin Tompo, and Rezki Antoni Suhaimi

The objectives of this research were to indenfity land suitability for shrimp culture development in Probolinggo Regency, East Java and to assess revitalization strategy of brackishwater pond through remediation research of soil and water quality. The primary data used including topography, land, and shore hidrology which were collected during field survey. Simple systematic random sampling was used to allocate sampling locations. Secondary data were used in this study such as weather data, tide data, topography map of Probolinggo area scale of 1:25,000 and satellite ALOS AVNIR-2, 2010. All data were analyzed using Geographic Information System (GIS) in 
order to obtain suitability sites assessment. The results show that from total potential area 2,143 ha, high suitable and moderate suitable were accounted for 56 ha and 618 ha, respectively. Those areas were distributed in subdistrict of Tongas and Pajarakan. Low suitable area was found about 1,235 ha, and located in subdistric of Tongas, Sumberasih, Dringu, Gending, Kraksaan, Pajarakan, and Paiton. The area of not suitable was about 234 ha, and distributed in subdistric of Sumberasih, Gending and Kraksaan. The productivity of brackishwater pond for shrimp culture can be increased through land suitability and brackishwater pond revitalization (remediation of soil and water quality).

\section{KEYWORDS: brackishwater pond, shrimp culture, land suitability and revitalization, Probolinggo Regency}

\section{PENDAHULUAN}

Kementerian Kelautan dan Perikanan telah menetapkan program industrialisasi tambak udang di beberapa kabupaten di Pulau Jawa, termasuk Kabupaten Probolinggo Provinsi Jawa Timur dengan komoditas unggulannya adalah udang (Anonim, 2011), Saat ini data dan informasi mengenai potensi lahan tambak udang di Kabupaten Lamongan seluas 27.126 ha, tidak ada lahan yang sangat sesuai, sedangkan lahan yang sesuai sebesar 24.550 ha. Potensi lahan tambak udang di Kabupaten Gresik seluas 31.939 ha dengan lahan yang sangat sesuai 799 ha dan yang sesuai 31.140 ha. Potensi lahan tambak udang di Kabupaten Pasuruan seluas 4.819 ha dengan lahan yang sangat sesuai seluas 259 ha dan yang sesuai 1.504 ha (Utojo et al., 2012; Utojo et al., 2013a; dan Utojo et al., 2013b).

Produksi udang windu di tambak Kabupaten Probolinggo pada tahun 2011 sebanyak 147,6 ton (Anonim, 2012). Peningkatan produksi melalui pengembangan usaha budidaya di kawasan industrialisasi tambak ini diharapkan dapat memberikan kontribusi yang sangat nyata terhadap peningkatan pendapatan petambak, daerah, dan sebagai sumber devisa negara.

Kawasan tambak industrialisasi budidaya udang di suatu daerah tentunya memiliki karakteristik sumberdaya alam yang berbeda dengan daerah lain. Pengelolaan tambak harus dilakukan berdasarkan kaidah ramah lingkungan yaitu dengan pendekatan keterpaduan dan keseimbangan ekologis antara ekosistem kawasan pesisir dengan perairan di sekitarnya serta peningkatan produksi dilakukan dengan merevitalisasi tambak.

Kondisi pertambakan industrialisasi di Kabupaten Probolinggo antara lain: 1) Memiliki sumberdaya lahan dan perairan yang sesuai untuk mengembangkan komoditas unggulan yaitu udang yang mampu meningkatkan pertumbuhan ekonomi daerah; 2) Setiap kecamatan memiliki luasan areal budidaya eksisting 400 ha, 3) Memiliki infrastruktur yang memadai untuk mendukung pengembangan sistem dan usaha perikanan terutama jaringan irigasi tambak, prasarana jalan, pasar, dan fasilitas umum lainnya; dan 4) Memiliki petambak yang mau dan berpotensi untuk mengembangkan kawasan perikanan budidaya secara mandiri. Hal ini sesuai dengan persyaratan suatu wilayah yang dapat dikembangkan menjadi kawasan tambak industrialisasi yang mendukung program minapolitan (Anonim, 2010).

Salah satu faktor penting yang menyebabkan rendahnya produktivitas tambak dan tidak berkelanjutan adalah kesalahan dalam pemilihan lokasi dan pemilihan komoditas yang dibudidayakan. Kajian tentang kesesuaian lahan tambak secara spasial dengan menggabungkan antara data lapangan dan data sekunder lainnya, diharapkan memberikan hasil dengan tingkat akurasi yang tinggi, sehingga dalam pelaksanaan budidaya, kemampuan daya dukung biofisik lahannya dapat disesuaikan dengan teknologi budidaya yang diterapkan. Hal ini akan berdampak berkurangnya degradasi mutu lingkungan hasil buangan tambak sehingga kerusakan ekosistem pesisir dapat dicegah. Menurut Dennis et al. (2004), aspek penting dalam kriteria penilaian kesesuaian lahan tambak yaitu topografi, lahan, hidrologi, iklim, dan vegetasi.

Penelitian ini bertujuan untuk menganalisis kesesuaian lahan tambak budidaya udang di kawasan industrialisasi Kabupaten Probolinggo Provinsi Jawa Timur dan mengkaji strategi revitalisasi tambak melalui hasil penelitian remediasi kualitas tanah dan air tambak. 


\section{BAHAN DAN METODE}

\section{Lokasi Penelitian}

Penelitian dilaksanakan di Kabupaten Probolinggo (Gambar 1). Survai lapangan dilakukan pada tanggal 16-26 Mei 2013. Lokasi survai lapangan dilakukan di Kecamatan Tongas, Dringu, Sumberasih, Gending, Pajarakan, Kraksaan, dan Paiton. Lokasi ini merupakan zona pengembangan industrialisasi budidaya udang berdasarkan Surat Keputusan Kementerian Kelautan dan Perikanan tahun 2011 . Survai lokasi dilakukan berdasarkan morfologi dan keragaman lahan budidaya tambak serta vegetasi mangrove sebagai zona penyangga.

\section{Pengumpulan Data}

Data yang dikumpulkan dalam penelitian ini adalah data primer dan sekunder. Data primer yang dikumpulkan meliputi: data tanah, hidrologi, jenis vegetasi, dan kualitas air. Data yang diukur langsung di lokasi penelitian berupa topografi pesisir, $\mathrm{pH}_{\mathrm{F}}$, dan $\mathrm{pH}_{\mathrm{FOx}}(\mathrm{pH}$ tanah yang dioksidasi dengan $30 \%$ hidrogen peroksida $\left(\mathrm{H}_{2} \mathrm{O}_{2}\right)$ ) serta potensial redoks. Contoh tanah yang diambil di lokasi penelitian yaitu pada dua kedalaman tanah yaitu 0-20 $\mathrm{cm}$ dan $20-40 \mathrm{~cm}$. Contoh tanah tersebut kemudian dianalisis di Laboratorium Tanah Balai Penelitian dan Pengembangan Budidaya Air Payau Maros berupa: tekstur tanah, bahan organik, $\mathrm{PO}_{4}$ nitrogen total ( $\mathrm{N}$ total), $\mathrm{Fe}$ dan $\mathrm{Al}$ mengikuti petunjuk Sulaeman et al. (2005) dan Agus et al. (2006).

Data hidrologi yang diukur adalah pasang surut dan kualitas air. Pasang surut diukur di perairan laut Kabupaten Probolinggo dengan papan pengamat pasang surut berskala $1 \mathrm{~cm}$, setiap jam selama 39 jam. Kualitas air diukur dan contoh air diambil di laut, muara sungai, sungai dan tambak sebanyak 61 titik pengamatan. Untuk pengukuran kualitas tanah dan pengambilan contoh tanah sebanyak 55 titik pengamatan dengan total 110 contoh tanah pada dua kedalaman tanah. Waktu dan lokasi pengukuran kualitas air dan pengambilan contoh air di tambak sama dengan pengukuran kualitas tanah dan pengambilan contoh tanah. Peubah kualitas air yang diukur di lokasi penelitian yaitu: suhu, $\mathrm{pH}$, salinitas, dan oksigen terlarut. Contoh air yang diambil di lokasi penelitian dianalisis di Laboratorium Air Balai Penelitian dan Pengembangan Budidaya Air Payau Maros berupa: $\mathrm{NH}_{4}, \mathrm{NO}_{2}, \mathrm{NO}_{3}$,

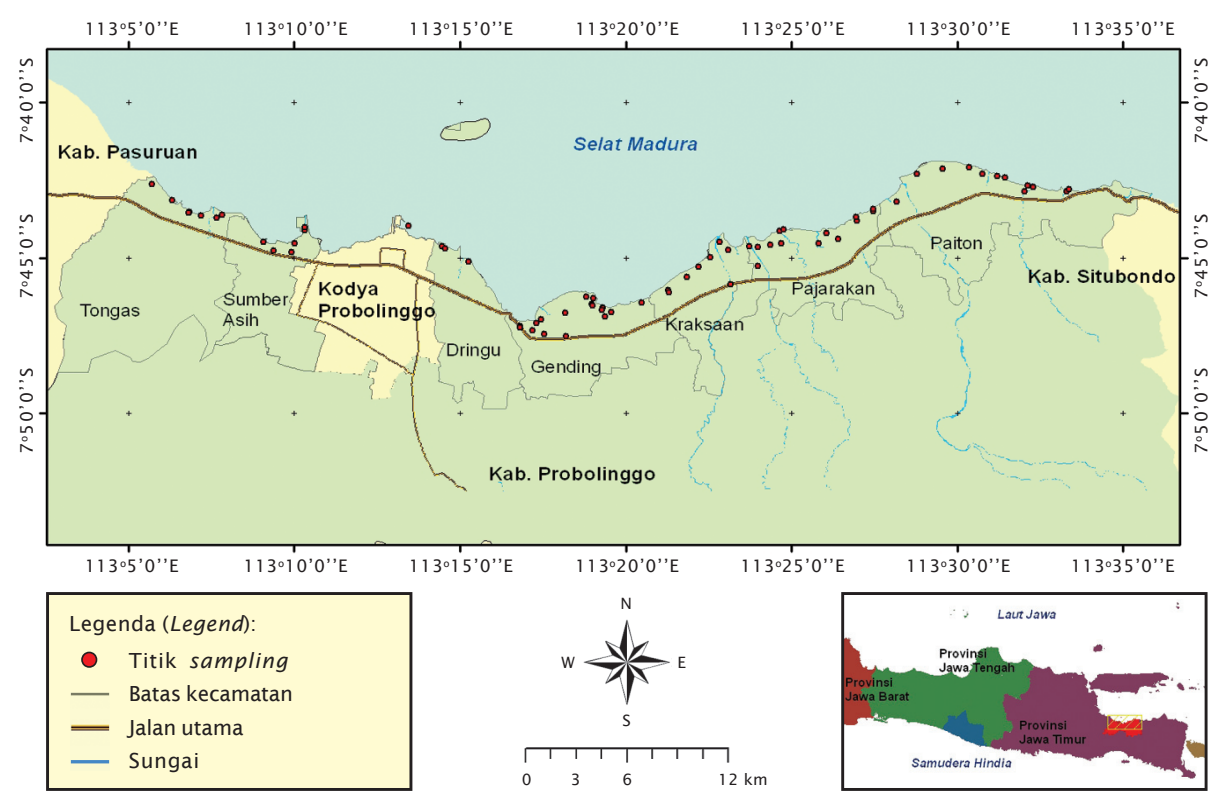

Gambar 1. Peta sebaran titik pengukuran dan pengambilan contoh untuk kesesuaian lahan budidaya tambak udang di Kabupaten Probolinggo, Jawa Timur

Figure 1. Map of sampling station for land suitability for brackishwater pond of shrimp culture in Probolinggo Regency, East Java 
$\mathrm{PO}_{4}$, bahan organik total, kekeruhan, dan padatan tersuspensi total mengikuti petunjuk Sutrisyani \& Rohani (2009) dan APHA (2005).

Jenis vegetasi mangrove didapatkan dengan cara mengidentifikasi setiap jenis vegetasi di wilayah pantai dan tambak, dan mengacu pada Bengen (2004). Setiap titik pengukuran dan pengambilan contoh di lokasi penelitian ditentukan posisinya dengan Global Positioning System (GPS) sebanyak 61 titik pengamatan. Jumlah titik yang diukur dan contoh yang diambil di lokasi penelitian ditentukan berdasarkan luas, kondisi dan tingkat keragaman lokasi. Sebaran titik yang diukur dan contoh yang diambil di lokasi penelitian disajikan pada Gambar 1.

Data sekunder yang dikumpulkan meliputi: laporan, data meteorologi, peta rupa bumi, dan citra satelit. Laporan hasil penelitian dan data meteorologi diperoleh dari berbagai instansi terkait. Peta yang dikumpulkan berupa peta jenis tanah skala 1:250.000 Provinsi Jawa Timur, peta curah hujan tahunan Provinsi Jawa Timur, peta kelerengan Kabupaten Probolinggo, peta rupabumi Indonesia digital skala 1:25.000 dan peta administrasi Kabupaten Probolinggo tahun 2007. Data citra ALOS AVNIR-2 akuisisi tahun 2010 yang digunakan telah terkoreksi secara radiometrik dan geometrik (JAXA, 2006). Kemudian dilakukan penajaman dan penapisan citra dengan bantuan program Er Mapper 7.1 untuk mendapatkan tampilan/gambar citra satelit yang tepat dan jelas dalam menentukan lokasi penelitian. Data citra ALOS memiliki empat kanal, direduksi dengan metode pemilihan kombinasi kanal spektral yang umum digunakan hanya tiga kanal yaitu kombinasi kanal 321 (Red Green Blue) dari sensor ALOS. Tampilan warna hasil kombinasi kanal akan memudahkan dalam menentukan batas-batas ekstrim antara setiap objek atau fenomena yang berbeda dalam citra. Klasifikasi dilakukan dengan metode terbimbing, hasil klasifikasi akan menggambarkan kondisi penutupan/penggunaan lahan aktual di lokasi penelitian pada setiap periode perekaman citra (Lillesand \& Kiefer, 2000).

\section{Pengolahan Data}

Pengolahan data terdiri atas data primer, sekunder, dan peta penutup/penggunaan lahan yang sudah dikumpulkan dan dianalisis secara spasial dengan sistem informasi geografis (SIG). Pada proses analisis tersebut da- lam program "arcview 3.3", data primer hasil dari setiap parameter disatukan dalam peta dasar digital dengan menginterpolasi pada setiap titik koordinat pengamatan menjadi area (polygon) menggunakan metode "Nearest Neighbor" (Morain, 1999). Dari hasil interpolasi setiap parameter yang diperoleh, kemudian disusun dalam bentuk peta tematik dengan layer-layer yang terpisah, melalui pertimbangan kriteria (skor) kesesuaian lahan budidaya tambak dengan tingkat pembobotan dan skala penilaian, kemudian di-overlay (tumpang susun). Kriteria ini mengacu pada persyaratan yang disarankan Poernomo (1992) dengan skala penilaian dan faktor pembobotan mengacu pada Utojo et al. (2009). Sistem klasifikasi kesesuaian lahan ini ditentukan sampai pada tingkat kategori kelas yaitu sangat sesuai, sesuai, cukup sesuai dan tidak sesuai. Hasil analisis spasial yang didapatkan berupa peta tematik kesesuaian lahan budidaya tambak di Kabupaten Probolinggo yang akurat dan terkini. Data dan informasi spasial yang diperoleh kemudian direkomendasikan kepada Pemerintah Daerah Kabupaten Probolinggo sebagai bahan penyusunan rencana tata ruang wilayah pesisir dalam mengalokasikan pengembangan industrialisasi budidaya udang dan peningkatan produksi yang dilakukan melalui revitalisasi tambak.

\section{HASIL DAN BAHASAN}

\section{Karakteristik Wilayah}

Berdasarkan hasil survai, topografi kawasan tambak di Kabupaten Probolinggo relatif datar dan berhadapan langsung dengan Laut Jawa dengan karakteristik perairan lautnya tenang, dangkal dan terbuka serta lebih banyak dipengaruhi oleh arus pasang surut. Di setiap wilayah kecamatan pesisir Kabupaten Probolinggo potensial untuk pengembangan budidaya tambak dan terdapat tambak terlantar bekas tambak udang intensif di antaranya di Kecamatan Gending, Dringu, Paiton, dan Sumberasih. Saat ini di semua kecamatan terdapat kegiatan budidaya tambak udang windu dan bandeng tradisional yang dikelola oleh masyarakat secara monokultur dan polikultur, hanya di Kecamatan Pajarakan dan Tongas terdapat pengusaha tambak yang membudidayakan udang vaname secara intensif.

Kawasan mangrove di Kabupaten Probolinggo tersebar di Kecamatan Tongas, Dringu, Sumberasih, Pajarakan, Gending, 
Kraksaan, dan Paiton. Jenis vegetasi yang ditemukan didominasi oleh tanaman tinjang (Rhizophora sp.), api-api (Avicennia sp.), dan bogem (Sonneratia sp.). Curah hujan di Kabupaten Probolinggo $1.481 \mathrm{~mm} /$ tahun, curah hujan tertinggi $190 \mathrm{~mm}$ dan terendah $4 \mathrm{~mm}$ dengan rata-rata $32 \mathrm{~mm}$. Curah hujan yang tinggi terjadi pada bulan November hingga Mei dan yang rendah pada bulan Juli hingga September setiap tahunnya (Anonim, 2012).

\section{Karakteristik Lahan}

Hasil analisis tekstur dan kualitas tanah di kedalaman $0-20 \mathrm{~cm}$ dan $20-40 \mathrm{~cm}$ cukup bervariasi (Tabel 1). Tekstur tanah tambak di lokasi penelitian didominasi oleh lempung berpasir hingga pasir berlempung. Menurut Poernomo (1992), tekstur tanah tambak yang baik untuk budidaya udang tradisional yaitu lempung liat berpasir, sedangkan untuk tambak udang semiintensif dan intensif yaitu lempung liat berpasir hingga lempung berpasir.

Hasil analisis kualitas tanah tambak di Kabupaten Probolinggo dapat dilihat pada Tabel 1. Secara umum, tanah tambaknya sebagian besar memiliki selisih nilai $\mathrm{pH}_{\mathrm{F}}$ dan $\mathrm{pH}_{\text {Fox }}$ yang relatif kecil yang berarti tidak memiliki potensi kemasaman dan kandungan sulfurnya rendah. Menurut Tarunamulia \& Mustafa (2009), lahan pesisir yang selisih nilai $\mathrm{pH}_{\mathrm{F}}$ dan $\mathrm{pH}_{\mathrm{FOx}}>3,5$ memiliki potensi kemasaman tanah tinggi, sebaiknya tidak dibuka dan dikelola untuk tambak, sedangkan lahan pesisir yang selisih nilai $\mathrm{pH}_{\mathrm{F}}$ dan $\mathrm{pH}_{\mathrm{FOx}} 0,5-3,5$, memiliki potensi kemasaman tanah sedang, bisa dibuka dan dikelola untuk tambak dengan syarat harus diremediasi melalui pengeringan, perendaman, pembilasan dan pengapuran. Lahan pesisir yang selisih nilai $\mathrm{pH}_{\mathrm{F}}$ dan $\mathrm{pH}_{\mathrm{FOX}}<$ 0,5 tidak memiliki potensi kemasaman tanah, baik dikelola untuk tambak tanpa meremediasi tanah.

Secara umum untuk mempercepat laju oksidasi dan proses perombakan bahan organik, diperlukan kapur bakar sekitar 1-5 ton per hektar tambak (Atmomarsono et al., 2011). Redoks potensial tanah dasar tambak pada saat kering sebaiknya minimal + $50 \mathrm{mV}$ (Poernomo, 2004). Kandungan Fe, Al, fosfat, bahan organik, dan $\mathrm{N}$ total tanah tambaknya masih baik, terutama untuk kegiatan budidaya tambak tradisional ikan dan udang. Nitrogen dan fosfat tanah termasuk unsur esensial untuk tumbuh dan berkembangnya produktivitas primer dan penambahan fosfat serta nitrogen dapat meningkatkan produksi ikan herbivor di tambak (Boyd, 1995). $\mathrm{N}$ total dan bahan organik tanah tambak menunjukkan nilai yang relatif rendah. Kandungan bahan organik tanah yang baik untuk budidaya tambak yaitu 1,7\%-5,2\% (Boyd et al., 2002).

\section{Karakteristik Hidrologi}

Hasil analisis kualitas air di lokasi penelitian disajikan pada Tabel 2. Secara umum kualitas air tambak masih baik sebagai media budidaya. Salinitas air tambak yang rendah didapatkan pada ekosistem daratan dan salinitas air tambak yang tinggi didapatkan pada ekosistem pesisir. Adanya variasi salinitas air tambak di lokasi penelitian, sebaiknya komoditas yang dibudidayakan bersifat eurihalin seperti udang windu, udang vaname, dan ikan bandeng. Udang vaname dapat hidup pada kisaran salinitas 1-2 ppt sampai air laut bersalinitas 40 ppt (Menz \& Blake, 1980). Hernandez et al. (2006) menyatakan bahwa pertumbuhan dan sintasan terbaik udang vaname dijumpai pada salinitas 33-40 ppt. Udang windu memiliki toleransi yang tinggi terhadap kisaran salinitas 3-45 ppt dan salinitas optimumnya yaitu 15-25 ppt (Poernomo, 1988). Suhu optimum untuk pertumbuhan udang windu berkisar $29^{\circ} \mathrm{C}-31^{\circ} \mathrm{C}$ dan untuk udang vaname yaitu $25^{\circ} \mathrm{C}-35^{\circ} \mathrm{C}$ (Ponce-Palatox et al., 1997). Tambak yang $\mathrm{pH}$-nya rendah, senyawa amonium terionisasi dan tidak bersifat toksik. Tambak yang $\mathrm{pH}$-nya tinggi, banyak ditemukan amonia yang tidak terionisasi dan bersifat toksik serta lebih mudah terserap ke dalam tubuh udang daripada amonium serta amonia bersifat toksik seiring dengan meningkatnya $\mathrm{pH}$, suhu, dan salinitas dengan kesadahan air tambak yang rendah (Effendi, 2003). Kandungan oksigen terlarut yang mematikan udang vaname adalah 1 mg/L (Hopkins et al., 1991). Pada saat operasional budidaya tambak, kandungan oksigen terlarut yang kurang dari $2 \mathrm{mg} / \mathrm{L}$ dapat mengakibatkan kematian udang dan batas optimumnya 4-7 mg/L (Poernomo, 1988). Kandungan nitrit yang masih dalam batas baik sebagai mutu air tambak udang yaitu $0,25 \mathrm{mg} / \mathrm{L}$ (Poernomo, 1992). Kandungan nitrat dan fosfat air tambak tradisional, sangat diperlukan untuk menstimulir pertumbuhan kelekap, plankton, dan lumut sebagai pakan alami utama bagi ikan dan udang. Kandungan nitrat air laut yang dipersyaratkan untuk kehidupan biota laut yaitu 0,008 mg/L (KLH, 2004). Kandungan fosfat di perairan alami berkisar 0,005-0,020 
Tabel 1. Kisaran nilai parameter tekstur dan kualitas tanah di lokasi tambak Kabupaten Probolinggo Provinsi Jawa Timur

Table 1. Value range of soil quality and texture parameters of brackishwater pond in Probolinggo Regency East Java Province

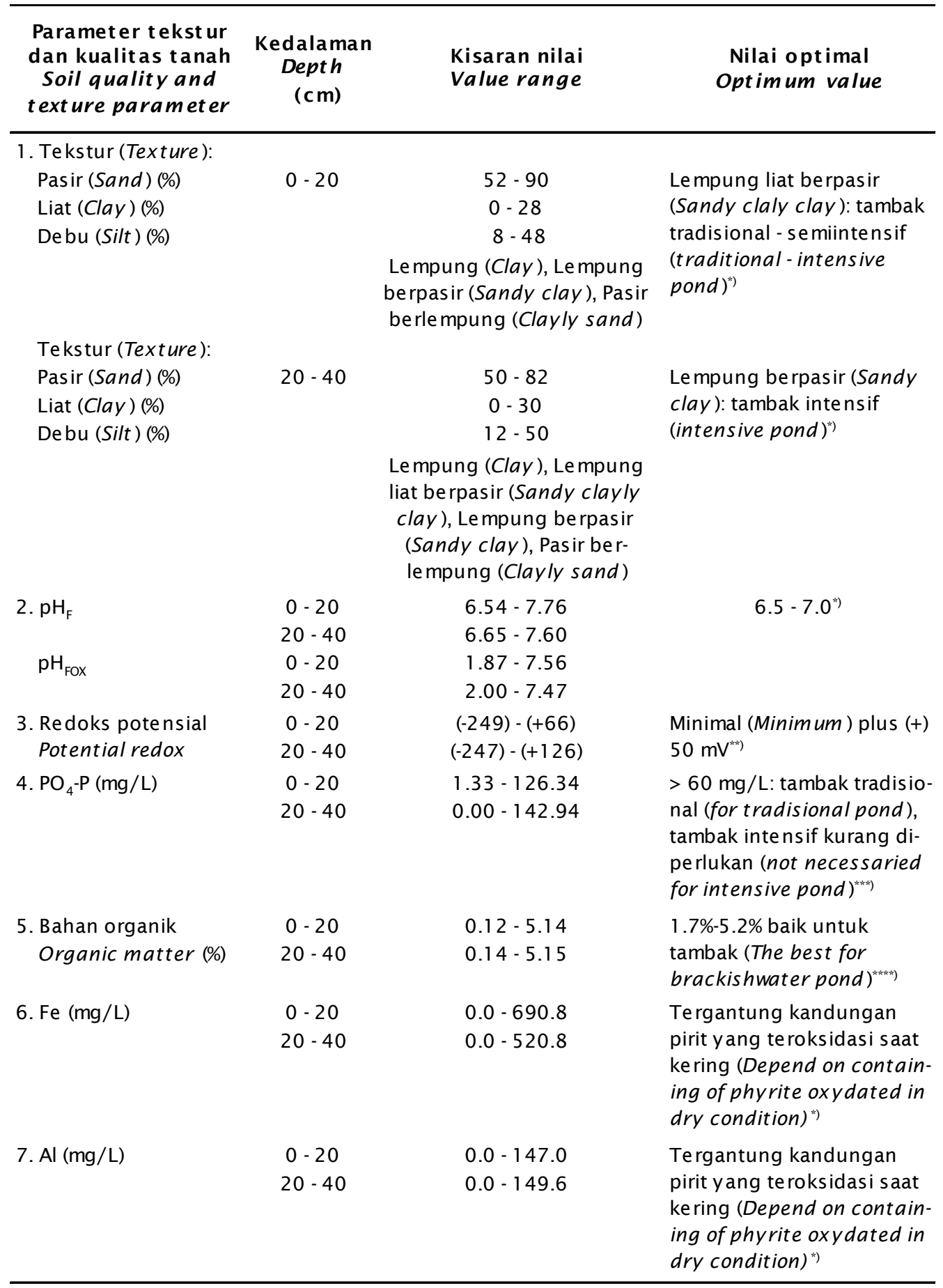


Lanjutan Tabel 1 (Table 1 continued)

\begin{tabular}{|c|c|c|c|}
\hline $\begin{array}{l}\text { Parameter tekst ur } \\
\text { dan kualit as tanah } \\
\text { Soil quality and } \\
\text { text ure parameter }\end{array}$ & $\begin{array}{l}\text { Kedalaman } \\
\text { Dept } h \\
(\mathrm{~cm})\end{array}$ & $\begin{array}{l}\text { Kisaran nilai } \\
\text { Value range }\end{array}$ & $\begin{array}{l}\text { Nilai optimal } \\
\text { Optimum value }\end{array}$ \\
\hline 8. S (\%) & $\begin{array}{c}0-20 \\
20-40\end{array}$ & $\begin{array}{l}0.04-0.54 \\
0.06-0.76\end{array}$ & $\begin{array}{l}\text { Tergantung konsentrasi } \\
\text { sulfat masam yang ada da- } \\
\text { lam tanah aluvial (Depend } \\
\text { on containing of acid sul- } \\
\text { fate soil in alluvial soil )") }\end{array}$ \\
\hline 9. N Total (Total N) (\%) & $\begin{array}{c}0-20 \\
20-40\end{array}$ & $\begin{array}{l}0.03-0.39 \\
0.02-0.19\end{array}$ & $\begin{array}{l}\text { Rasio C: } \mathrm{N} \text { yang ideal untuk } \\
\text { tambak berkisar } 8: 1-12: 1 \\
\text { (Range of C:N is ideal for } \\
\text { brackishwater pond } 8: 1 \text { - } \\
12: 1)^{\text {:.*k**)}}\end{array}$ \\
\hline
\end{tabular}

Sumber (Resources):

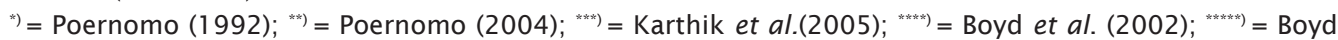
(2008)

Tabel 2. Kisaran nilai parameter kualitas air di lokasi tambak Kabupaten Probolinggo, Jawa Timur

Table 2. Value range of water quality parameters of brackishwater pond location in Probolinggo Regency, East Java

\begin{tabular}{|c|c|c|c|}
\hline $\begin{array}{c}\text { Parameter kualitas air } \\
\text { Water quality parameters }\end{array}$ & $\begin{array}{l}\text { Sat uan } \\
\text { Unit }\end{array}$ & $\begin{array}{l}\text { Kisaran nilai } \\
\text { Value range }\end{array}$ & $\begin{array}{l}\text { Nilai optimal } \\
\text { Optimum value }\end{array}$ \\
\hline \multicolumn{4}{|l|}{ 1. Salinitas (Salinity): } \\
\hline - Laut (Sea) & ppt & $20-34$ & $\left.30-35^{*}\right)$ \\
\hline - Sungai (River) & $\mathrm{ppt}$ & $5-16$ & $10-20 *$ \\
\hline - Tambak (Pond) & ppt & $5-32$ & $\left.15-25^{*}\right)$ \\
\hline 2. Suhu air (Water temperature) & ${ }^{\circ} \mathrm{C}$ & $28-35.4$ & $29-31 *$ \\
\hline 3. $\mathrm{pH}$ & & $7.34-9.09$ & $7.0-8.5^{* *}$ \\
\hline $\begin{array}{l}\text { 4. Oksigen te rlarut (DO) } \\
\text { Dissolved oxygen }\end{array}$ & $\mathrm{mg} / \mathrm{L}$ & $6.64-8.94$ & $4-7^{* 1}$ \\
\hline 5. $\mathrm{NH}_{3}-\mathrm{N}$ & $\mathrm{mg} / \mathrm{L}$ & $0.0020-3.2429$ & $0.30^{* *}$ \\
\hline 6. $\mathrm{NO}_{2}-\mathrm{N}$ & $\mathrm{mg} / \mathrm{L}$ & $0.0004-0.1649$ & $0.25^{*}$ \\
\hline 7. $\mathrm{NO}_{3}-\mathrm{N}$ & $\mathrm{mg} / \mathrm{L}$ & $0.0015-4.9473$ & $0.008^{* *}$ \\
\hline 8. $\mathrm{PO}_{4}^{-}-\mathrm{P}$ & $\mathrm{mg} / \mathrm{L}$ & $0.0021-3.3245$ & $0.015^{* *}$ \\
\hline $\begin{array}{l}\text { 9. Padatan tersuspensi total } \\
\text { Total suspended solute }\end{array}$ & $\mathrm{mg} / \mathrm{L}$ & $1-181$ & $<25^{* \cdots *}$ \\
\hline $\begin{array}{l}\text { 10. Bahan organik total } \\
\text { Total organic matter }\end{array}$ & $\mathrm{mg} / \mathrm{L}$ & $10.42-63.19$ & $29.50 *$ \\
\hline 11. Fe & $\mathrm{mg} / \mathrm{L}$ & $0.0001-0.0866$ & $0.01^{* \ldots \ldots *}$ \\
\hline
\end{tabular}

Sumber (Resources):

") = Poernomo (1992); ${ }^{* *}$ ) = Kementerian Kependudukan dan Lingkungan Hidup (Ministry of Demography

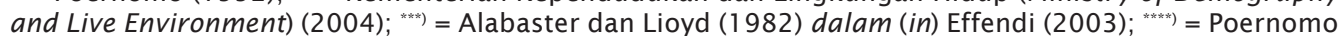
(1988) 


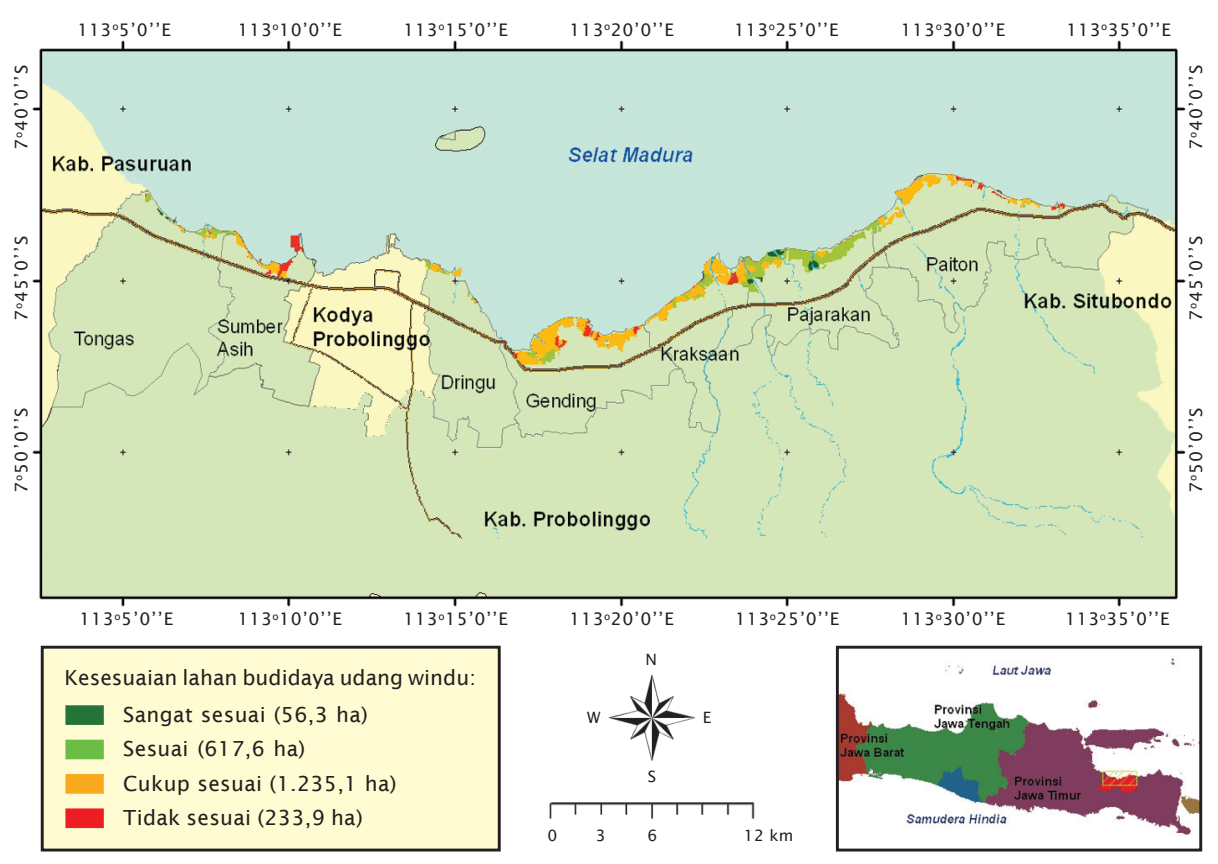

Gambar 2. Peta kesesuaian lahan tambak budidaya udang di Kabupaten Probolinggo, Jawa Timur

Figure 2. Map of land suitability for brackishwater pond of shrimp culture in Probolinggo Regency, East Java

$\mathrm{mg} / \mathrm{L}$, sedangkan di dalam air tanah biasanya sekitar 0,02 mg/L (Effendi, 2003). Padatan tersuspensi $<25 \mathrm{mg} / \mathrm{L}$, baik sebagai media budidaya ikan; 25-80 mg/L, sedikit berpengaruh sebagai media budidaya ikan; 81-400 mg/L, kurang baik sebagai media budidaya ikan; dan $>400 \mathrm{mg} / \mathrm{L}$, tidak baik sebagai media budidaya ikan (Effendi, 2003). Perairan tambak yang memiliki kandungan bahan organik total di atas $26 \mathrm{mg} / \mathrm{L}$, tergolong subur. Batas nilai kandungan besi fero yang aman sebagai media budidaya tambak udang yaitu $0,03 \mathrm{mg} / \mathrm{L}$ dengan optimumnya $0,01 \mathrm{mg} / \mathrm{L}$ (Poernomo, 1988).

Tinggi permukaan air laut saat surut dan pasang di Kabupaten Probolinggo yaitu 0 dan $203 \mathrm{~cm}$ dengan tunggang pasang $203 \mathrm{~cm}$. Kondisi jalur hijau di lokasi penelitian mengalami kritis dengan kisaran lebar 50-75 m. Berdasarkan Keppres No. 32 tahun 1990, lebar jalur hijau di sepanjang pesisir Kabupaten Probolinggo yang harus dipenuhi oleh pengguna, minimal $130 \times$ tunggang pasang $2,03 \mathrm{~m}$ $=263,9 \mathrm{~m}$ yang diukur mulai dari garis pantai saat surut terendah dan $100 \mathrm{~m}$ di kanan kiri sungai besar serta $50 \mathrm{~m}$ di kanan kiri sungai kecil di luar pemukiman.

\section{Kesesuaian Lahan Budidaya Tambak}

Gambar 2 menampilkan hasil analisis kesesuaian lahan tambak secara spasial di Kabupaten Probolinggo. Berdasarkan hasil analisis tersebut, didapatkan lahan tambak budidaya udang berkelanjutan seluas 2.143 ha. Lahan yang sangat sesuai untuk budidaya udang yaitu 56 ha dan sesuai 618 ha. Kawasan tersebut tersebar di Kecamatan Tongas dan Pajarakan. Lahan yang cukup sesuai sebesar 1.235 ha, tersebar di Kecamatan Tongas, Sumberasih, Dringu, Gending, Kraksaan, Pajarakan, dan Paiton. Sedangkan lahan yang tidak sesuai untuk budidaya udang adalah 234 ha, terdapat di Kecamatan Sumberasih, Gending, dan Kraksaan.

Lahan yang sangat sesuai dialokasikan untuk kegiatan budidaya udang sistem semiintensif hingga intensif, yang sesuai untuk kegiatan budidaya udang (monokultur) atau udang bersama bandeng (polikultur) sistem tradisional plus, dan yang cukup sesuai untuk kegiatan budidaya udang (monokultur), udang bersama bandeng atau rumput laut (polikultur) sistem tradisional. 


\section{Revitalisasi Tambak Udang}

Strategi revitalisasi tambak dilakukan melalui perbaikan (remediasi) kualitas tanah dan air tambak. Langkah-langkah yang dapat dilakukan meliputi:

\section{Perbaikan kualitas tanah tambak udang di lahan mangrove dengan cara reklamasi}

Untuk mengurangi/menghilangkan kemasaman, konsentrasi Fe dan Al serta meningkatkan derajat kemasaman tanah di dasar tambak, dapat dilakukan melalui reklamasi seperti penjemuran, perendaman, dan pencucian serta pengapuran tambak. Dengan penjemuran dan perendaman terjadi pemecahan senyawa pirit yang tidak dapat larut menjadi senyawa yang larut dalam air, kemudian dilakukan pencucian untuk menghilangkan konsentrasi Fe dan Al yang masih mengendap di dasar tambak serta pengapuran untuk meningkatkan derajat kemasaman tanah dasar tambak.

Pengapuran untuk memperbaiki kualitas tanah berupa penurunan kemasaman dan kandungan unsur toksik serta peningkatan ketersediaan unsur hara makro. Pada tambak yang tanahnya tidak bermasalah seperti unit tambak di Kabupaten Probolinggo, sebaiknya digunakan kapur dolomit $\left(\mathrm{CaMg}\left(\mathrm{CO}_{3}\right)_{2}\right)$ dan kaptan atau kapur pertanian $\left(\mathrm{CaCO}_{3}\right)$. Kedua jenis kapur ini bermanfaat untuk meningkatkan $\mathrm{pH}$ tanah atau menetralisir kemasaman yang masih ada dan menambah $\mathrm{Ca}$ dan $\mathrm{Mg}$ (dari dolomit) pada tanah. Dolomit umumnya digunakan sebagian besar pembudidaya tambak udang sebagai kapur susulan, dapat meningkatkan $\mathrm{pH}$ air tidak terlalu drastis dan daya sangga air serta sebagai sumber Ca dan Mg yang sangat diperlukan udang dalam pembentukan kulitnya (Mustafa et al., 2010). Kapur bakar $(\mathrm{CaO})$, digunakan oleh pembudidaya tambak udang sebagai disinfektan, memperbaiki kualitas tanah dan air serta diaplikasikan sebagai kapur awal. Kapur awal umumnya diaplikasikan pada saat persiapan tambak dan kapur susulan saat budidaya udang sedang berlangsung dengan dosis yang lebih tinggi dibandingkan dengan kapur susulan.

Menurut Boyd (2008), dosis kapur pertanian (kaptan) $\left(\mathrm{CaCO}_{3}\right)$ dan kapur mati $\left(\mathrm{Ca}(\mathrm{OH})_{2}\right.$ yang digunakan pada tahap persiapan tambak dengan $\mathrm{pH}$ tanah sebagai berikut: pada $\mathrm{pH}<5$ pemberian dosis kaptan $3.000 \mathrm{~kg} /$ ha dan kapur mati $2.250 \mathrm{~kg} / \mathrm{ha}$, pada pH 5-5,4 pemberian dosis kaptan $2.500 \mathrm{~kg} / \mathrm{ha}$ dan kapur mati $1.870 \mathrm{~kg} / \mathrm{ha}$, pada $\mathrm{pH}$ 5,5-5,9 pemberian dosis kaptan $2.000 \mathrm{~kg} / \mathrm{ha}$ dan kapur mati 1.500 $\mathrm{kg} / \mathrm{ha}$, pada $\mathrm{pH}$ 6-6,4 pemberian dosis kaptan $1.500 \mathrm{~kg} / \mathrm{ha}$ dan kapur mati $1.125 \mathrm{~kg} / \mathrm{ha}$, dan pH 6,5-7 pemberian dosis kaptan 1.000 ton dan kapur mati 750 kg/ha.

\section{Perbaikan kualitas air tambak udang dengan menggunakan saponin}

Saponin merupakan pestisida organik atau produk sampingan dari proses pembuatan minyak dari biji tanaman teh yang aplikasinya di tambak tidak berdampak negatif terhadap kondisi kualitas tanah. Biji tanaman teh yang mengandung $10 \%-15 \%$, efektif untuk mematikan hama ikan (ikan liar) yang masuk dalam tambak, namun tidak mematikan udang yang dibudidayakan. Menurut Atmomarsono et al. (2011), umumnya pemberantasan hama ikan di tambak udang dengan saponin $15-30 \mathrm{mg} / \mathrm{L}$, yang dilakukan saat kondisi tambak masih berair (sekitar $10 \mathrm{~cm}$ ). Makin rendah salinitas air tambak diperlukan konsentrasi saponin yang lebih tinggi, misalnya pada salinitas air di bawah 5 ppt diperlukan $30 \mathrm{mg} / \mathrm{L}$ saponin (30 kg saponin per hektar tambak dengan kedalaman air rata-rata $10 \mathrm{~cm}$ ) yang ditambah kaporit 1-2 mg/L (1-2 kg per hektar tambak dengan kedalaman air rata-rata $10 \mathrm{~cm}$ ). Saponin lebih efektif hasilnya dalam mematikan ikan liar di tambak seiring dengan salinitas air yang lebih tinggi. Shariff et al. (2000), saponin tidak hanya mematikan hama ikan, tetapi juga dapat merangsang pergantian kulit udang. Saponin dosis 2-3 mg/L selama 24 jam diaplikasikan untuk merangsang pergantian kulit pada udang windu dan saponin dosis 20-30 $\mathrm{mg} / \mathrm{L}$, direkomendasikan untuk membasmi penyakit bintik hitam (black spot disease) pada udang. Saponin juga berfungsi sebagai pupuk organik yang dapat merangsang pertumbuhan alga di tambak (Liao et al., 2000).

\section{Perbaikan kualitas air tambak udang dengan pemberian bakteri probiotik}

Bakteri probiotik adalah bakteri yang mampu memperbaiki kualitas air tambak yaitu dapat menurunkan kandungan bahan organik total, amoniak dan nitrit serta dapat menghambat perkembangbiakan organisme patogen yaitu bakteri kunang-kunang (Vibrio harveyi) dan penyakit bintik putih pada karapaks udang yang disebabkan oleh mikroba patogen dari jenis virus (WSSV) (Atmomarsono et al., 2011). Menurut Verschuere et al. (2000) 
dan Poernomo (2004), penggunaan bakteri probiotik merupakan salah satu cara untuk menanggulangi penyakit pada budidaya udang.

Hanya sembilan isolat dari 37 isolat yang layak menghambat $V$. harveyi dan menjadi kandidat bakteri probiotik untuk budidaya udang windu. Kesembilan isolat tersebut diberi nama bakteri probiotik RICA (Riset Institute for Coastal Aquaculture-Balai Penelitian dan Pengembangan Budidaya Air Payau) dan telah diaplikasikan di unit tambak beberapa kabupaten di Sulawesi Selatan. Menurut Atmomarsono et al. (2011), cara aplikasinya di tambak yaitu setelah bakteri probiotik dikultur selama 4-5 hari di dalam ember besar bertutup, aerasi dimatikan dan bakteri tersebut siap digunakan di tambak dengan ember volume 10-15 L sebagai berikut: dosis bakteri 0,2-1 mg/L (2-10 L per hektar tambak udang windu tradisional plus dengan kedalaman air $1 \mathrm{~m})$; 1-5 mg/L di tambak udang windu semiintensif dengan padat tebar hingga 10 ekor/ $\mathrm{m}^{2} ; 5-10 \mathrm{mg} / \mathrm{L}$ di tambak udang windu intensif dengan padat tebar hingga $20 \mathrm{ekor} / \mathrm{m}^{2}$. Pemberian bakteri probiotik dilakukan seminggu sekali untuk budidaya udang windu tradisional plus dan semiintensif. Untuk budidaya intensif diperlukan pemberian 1-2 kali/ minggu tergantung kondisi airnya. Pencegahan penyakit bintik putih dapat dilakukan secara tidak langsung dengan menggunakan bakteri probiotik RICA yang dikombinasikan dengan aplikasi kapur dolomit 3-5 mg/L (30$50 \mathrm{~kg} /$ ha dengan kedalaman air $1 \mathrm{~m}$ ) terutama setelah hujan, dengan tujuan untuk mengendalikan penumpukan bahan organik di dalam air dan dasar tambak (Atmomarsono et al., 2011).

\section{Perbaikan kualitas air tambak udang dengan sistem bioflok}

Penggunaan pakan yang berprotein tinggi dalam jumlah banyak pada budidaya udang vaname intensif di tambak berdampak meningkatnya limbah total amoniak nitrogen (TAN). Untuk mengurangi akumulasi limbah tersebut yang umum dilakukan dengan pergantian air secara regular dalam jumlah banyak. Hal ini dapat memicu terjadinya serangan penyakit, terutama jika kondisi kualitas air sumber (laut atau sungai) kurang baik. Alternatif lain untuk mengurangi akumulasi TAN yang efektif dan efisien di tambak yaitu mengelola budidaya udang vaname intensif sistem bioflok dengan sedikit pergantian air dan dapat mengurangi penggunaan pakan buatan. Prinsip kerja sistem bioflok dapat mengkonversi TAN dan limbah organik nitrogen menjadi biomassa bakteri heterotrof (bakteri yang mampu memanfaatkan bahan organik secara langsung). Proses konversi tersebut akan terjadi dengan baik jika rasio antara karbon organik dan nitrogen $(\mathrm{C} / \mathrm{N})$ dalam air tambak 10-20 pada kondisi aerob (kandungan oksigen terlarut $>3 \mathrm{mg} / \mathrm{L}$ ) dengan padatan/partikel tetap tersuspensi. Pada saat pengelolaan budidaya sedang berjalan, timbunan kandungan amoniak semakin meningkat karena akumulasi eskresi, kotoran dan sisa pakan udang menyebabkan nilai rasio $\mathrm{C} / \mathrm{N}$ dalam tambak menjadi sangat rendah. Untuk meningkatkan rasio $\mathrm{C} / \mathrm{N}$ dalam tambak, harus ditambahkan beberapa bahan karbohidrat (sumber C-organik), salah satunya yaitu molase, tepung tapioka, glukosa, gliserol, atau sukrosa. Bakteri heterotrof (bakteri probiotik) akan menyatu dengan mikroorganisme lainnya (plankton, fungi, protozoa, ciliata, dan nematoda) serta partikel organik lainnya membentuk bioflok. Bioflok yang terbentuk mengandung nutrisi seperti protein, lemak, karbohidrat dan mineral yang cukup baik bagi pertumbuhan udang. Terdapatnya bioflok dalam tambak memberikan kesempatan udang untuk memanfaatkan bioflok tersebut sebagai makanan pengganti sebagian pakan buatan yang diberikan. Pemanfaatan bioflok pada pengelolaan budidaya udang di tambak, selain untuk mengifisiensikan biaya produksi, juga mampu meminimalisir risiko serangan penyakit (Gunarto et al., 2011).

Menurut Gunarto et al. (2011) dan Poernomo (2004), prosedur kultur probiotik yaitu merebus air tambak sebanyak $200 \mathrm{~L}$ sampai mendidih, dimasukkan dedak halus 10 $\mathrm{kg}$, tepung ikan $5 \mathrm{~kg}$, dan molase $5 \mathrm{~L}$ secara bersama-sama ke dalam air yang sedang mendidih dan diaduk selama 30 menit, kemudian didinginkan dalam keadaan wadah yang tertutup. Setelah bahan kultur dingin, dimasukkan ragi roti $20 \mathrm{~g}$ dan probiotik $2 \mathrm{~L}$, kemudian diaerasi selama dua hari. Pada hari ke tiga setelah diaerasi biasanya bau tape, sebagai indikasi populasi bakteri probiotik mencapai 109-10 $12 \mathrm{CFU} / \mathrm{mL}$.

Selanjutnya probiotik tersebut siap digunakan dengan cara ditebar merata ke seluruh permukaan air tambak dengan dosis $5 \mathrm{ppm}$ (75 L/ha tambak dengan kedalaman air 1,5 m). Sebaiknya digunakan beberapa jenis probiotik secara bergiliran dalam satu minggu, sehingga 
saling melengkapi dalam mempercepat terbentuknya bioflok. Penebaran probiotik pertama kali di tambak sebaiknya dilakukan sebelum benur ditebar dan selanjutnya setiap 1-2 hari selama pemeliharaan udang. Setelah satu bulan pemeliharaan udang di tambak, mulai ditambahkan molase/tepung tapioka sebagai sumber C-organik (40\%-60\%) yang terlebih dulu dilarutkan dengan air, ke dalam air tambak pada pagi hari untuk meningkatkan rasio C/N: 10-20. Setelah satu bulan penambahan C-organik seperti molase, biasanya bioflok mulai tumbuh dalam tambak. Pemantauan pertumbuhan bioflok dilakukan setiap dua hari dengan menggunakan tabung cone. Komponen bioflok yang baik di tambak biasanya terdiri dari jenis bakteri Bacillus sp., $B$. subtilis, B. cereus, Lactobacillus, Zooglea, dan mikroorganisme lainnya seperti plankton yaitu diatom, Chlorella sp., Brachionus sp., copepoda, protozoa, cacing, dan lain-lain. Bioflok yang baik jika warna air tambaknya coklat yang didominasi oleh bakteri heterotrof aerob; cukup baik jika warna air tambaknya hijau yang didominasi oleh bakteri fotosintetik (Cyanobakter); dan tidak baik jika warna air tambaknya hitam yang didominasi bakteri terakumulasi besi.

\section{Perbaikan kualitas tanah dan air tambak udang dengan pemberian pupuk}

Setelah 1-2 minggu pengeringan dan tanah terlihat retak-retak (tergantung kondisi cuaca), maka dilakukan pemupukan tambak sesuai kebutuhan. Pemupukan di tambak tradisional hingga tradisional plus, masih memerlukan pupuk organik, urea, dan SP-36 yang aplikasi dan dosisnya tergantung kondisi tanah dan musim penebaran. Pemupukan bertujuan untuk meningkatkan kandungan nutrien, menstimulasi pertumbuhan plankton, klekap dan lumut sebagai pakan alami ikan dan udang. Pupuk anorganik (urea dan SP-36) aplikasinya di tambak sebagai pupuk awal pada persiapan dan pupuk susulan pada saat pelaksanaan budidaya. Sedangkan pupuk organik aplikasinya di tambak sebagai pupuk awal langsung ditebar secara merata di dasar tanah tambak saat persiapan. Secara umum, diperlukan pupuk dasar (awal) yaitu pupuk organik 400$1.000 \mathrm{~kg} / \mathrm{ha}$, urea $200-400 \mathrm{~kg} / \mathrm{ha}$, dan SP-36 $100-200 \mathrm{~kg} / \mathrm{ha}$. Pada musim hujan penggunaan urea dapat dikurangi karena adanya masukan nitrogen dari air hujan. Tambak yang relatif dekat dengan laut, umumnya memerlukan urea lebih banyak daripada yang jauh dari laut.
Untuk mempertahankan warna air tambak pada pelaksanaan budidaya agar mendekati warna hijau kecoklatan (warna air tambak yang baik untuk budidaya udang windu) dilakukan pemupukan susulan dengan urea dan SP-36 sekitar $10 \%$ dari pupuk dasarnya (tergantung warna airnya) serta aplikasi bakteri probiotik tertentu. Untuk warna air tambak yang cenderung hijau muda kekuningan, diperlukan pupuk susulan SP-36 lebih banyak daripada ureanya. Sebaliknya jika warna air cenderung coklat kemerahan, maka diperlukan pupuk susulan lebih banyak daripada SP-36 (Atmomarsono et al., 2011).

\section{KESIMPULAN DAN SARAN}

Hasil analisis kesesuaian lahan tambak udang berkelanjutan di Kabupaten Probolinggo menggunakan SIG, didapatkan lahan tambak budidaya udang seluas 2.143 ha. Lahan yang sangat sesuai untuk budidaya udang yaitu 56 ha dan yang sesuai 618 ha. Lahan tersebut tersebar di Kecamatan Tongas dan Pajarakan. Lahan yang sangat sesuai, dialokasikan untuk pengelolaan budidaya udang semiintensif hingga intensif, lahan yang sesuai, untuk budidaya udang tradisional. Produksi tambak udang dapat ditingkatkan melalui aplikasi tingkat teknologi budidaya sesuai dengan kelas lahan yang dianalisis dengan merevitalisasi tambak melalui remediasi kualitas tanah dan air tambak.

\section{DAFTAR ACUAN}

Agus, Yusrial, F., \& Sutono. (2006). Penetapan tekstur tanah. Dalam: Kurnia, U., Agus, F., Adimihardja, A., dan Dariah, A. (Eds.). Sifat Fisik Tanah dan Metode Analisisnya. Balai Besar Penelitian dan Pengembangan Sumberdaya Lahan Pertanian, Bogor, hlm. 4362.

Anonim. (2012). Kabupaten Probolinggo Dalam Angka 2012. Kerjasama Badan Pusat Statistik Kabupaten Probolinggo dan Pemerintah Daerah Kabupaten Probolinggo, 332 hlm.

Anonim. (2011). Budidaya Air Payau. http:// www.pasuruankab.go.id/potensi-46budidaya-air-payau.html. [Diakses 25/11/ 2012].

Anonim. (2010). Pedoman Perencanaan Pengembangan Kawasan Perikanan Budidaya (Minapolitan). Direktorat Prasarana dan Sarana Budidaya, Direktorat Jenderal Perikanan Budidaya, Kementerian Kelautan 
dan Perikanan, Jakarta, $48 \mathrm{hlm}$.

APHA (American Public Health Association). (2005). Standart Methods for Examination of Water and Wastewater. APHA-AWWAWEF, Washington, DC, 1,185 pp.

Atmomarsono, M., Muliani, Nurbaya, Susianingsih, E., Nurhidayah, \& Rachmansyah. (2011). Petunjuk Teknis Aplikasi Bakteri Probiotik RICA pada Budidaya Udang Windu di Tambak. Badan Penelitian dan Pengembangan Kelautan dan Perikanan, Pusat Penelitian dan Pengembangan Perikanan Budidaya, Balai Penelitian dan Pengembangan Budidaya Air Payau, Maros, $20 \mathrm{hlm}$.

Bengen, D.G. (2004). Pedoman Teknis Pengenalan dan Pengelolaan Ekosistem Mangrove. Pusat Kajian Sumberdaya Pesisir dan Lautan, Institut Pertanian Bogor, Bogor, 59 hlm.

Boyd, C.E. (1995). Bottom Soil, Sediment, and Pond Aquaculture. Chapman and Hall, New York, $46 \mathrm{pp}$.

Boyd, C.E., Wood, C.W., \& Thunjai, T. (2002). Aquaculture Pond Bottom Soil Quality Management. Oregon State University. Corvallis, Oregon, $41 \mathrm{pp}$.

Boyd, C.E. (2008). Pond bottom soil analysis. Global Aquaculture Advocate September/ October 2008, p. 91-92.

Dennis, M., Tammy, T., Baldwin, K., \& Kevin, F. (2004). Aquaculture development potential in Arizona: a GIS-based approach. World Aquaculture, 34(4), 32-35.

Effendi, H. (2003). Telaah Kualitas Air Bagi Pengelolaan Sumberdaya dan Lingkungan Perairan. Penerbit Kanisius (Anggota IKAPI), Yogyakarta, $258 \mathrm{hlm}$.

Gunarto, Usman, Mansyur, A., \& Rangka, N.A. (2011). Petunjuk Teknis Budidaya Udang Vaname Intensif Sistem Bioflok. Badan Penelitian dan Pengembangan Kelautan dan Perikanan, Pusat Penelitian dan Pengembangan Perikanan Budidaya, Balai Penelitian dan Pengembangan Budidaya Air Payau, Maros, $23 \mathrm{hlm}$.

Hernandez, M.R., Buckle, L.F.R., Palacios, E., \& Baron, B.S. (2006). Preferential behavior of white shrimp Litopenaeus vannamei (Boone, 1931) by progressive temperaturesalinity simultaneous interaction. Journal of Thermal Biology, 31, 565-572.

Hopkins, J.S., Stokes, A.D., Browdy, C.L., \& Sandifer, P.A. (1991). The relationship between feeding rate, padlle wheel rate and expected dawn dissolved oxygen in in- tensive shrimp ponds. Aquacultural Engineering, 10, 281-290.

JAXA. (2006). ALOS/AVNIR-2 Level 1 product format description. Revision J. JAXA-Earth Observation Research Center, 140 pp.

Karthik, M., Suri, J., Saharan, N., \& Biradar, R.S. (2005). Brackishwater aquaculture site selection in Palghar Taluk, Thane District of Maharashtra, India, using the techniques of remote sensing and Geographical Information System. Aquacultural Engineering, 32, 285-302.

Kementerian Lingkungan Hidup (KLH). (2004). Keputusan Menteri Negara Kependudukan dan Lingkungan Hidup, No. 51 tahun 2004, tanggal 8 April 2004 tentang Baku Mutu Air Laut. Kementerian Lingkungan Hidup, Jakarta, $11 \mathrm{hlm}$.

Lillesand, T.M. \& Kiefer, R.W. (2000). Remote Sensing and Image Interpretation. Fourth Edition. John Wiley \& Sons. New York, USA, $736 \mathrm{pp}$.

Liao, E.C., Guo, J.J., \& Su, M.S. (2000). The use of chemicals in aquaculture in Taiwan, Province of China. In: Arthur, J.R., C.R. LavillaPitogo and R.P. Subasinghe (Eds.). Use of Southeast Asian Fiseries Development Center Aquaculture Department, Tigbauan, Iloilo, Philippines, p. 193-205.

Menz, A. \& Blake, B.F. (1980). Experiments on the growth of Penaeus vannamei Boone. Journal of Experimental Marine Biology and Ecology, 48, 99-111.

Morain, S. (1999). GIS Solution in Natural Resource Management: Balancing the Technical-Political Equation. OnWord Press, USA, $361 \mathrm{pp}$.

Mustafa, A., Sapo, I. \& Paena, M. (2010). Studi penggunaan produk kimia dan biologi pada budidaya udang vaname (Litopenaeus vannamei) di tambak Kabupaten Pesawaran Provinsi Lampung, 1(5), 115-133.

Poernomo, A. (1988). Pembuatan Tambak di Indonesia. Seri Pengembangan No. 7, 1988. Departemen Pertanian, Badan Penelitian dan Pengembangan Pertanian, Balai Penelitian Perikanan Budidaya Pantai, Maros, 30 hlm.

Poernomo, A. (1992). Pemilihan Lokasi Tambak Udang Berwawasan Lingkungan, CRIFI Pub., $40 \mathrm{hlm}$.

Poernomo, (2004). Technology of probiotics to solve the problems in shrimp pond culture and the culture environment. Paper presented in The National Symposium on 
Development and Scientific and Technology Innovation in Aquaculture, January 27 29, 2004, Patrajasa Hotel, Semarang, 25 pp.

Ponce-Palatox, J., Martinez-Palacios, C.A., \& Ross. L.G. (1997). The effect of salinity and temperature on the growth and survival rates of juvenile white shrimp, Penaeus vannamei, Boone, 1931. Aquaculture, 157, 107-115.

Reid, G.K. (1961). Ecology Inland Water Estuaries. Rein Hald Published Co. New York, 37 pp.

Shariff, M., Nagaraj, G., China, F.H.C., \& Wang, Y.G. (2000). The use of chemicals in aquaculture in Malaysia and Singapore. In: Arthur, J.R., C.R. Lavilla-Pitogo and R.P. Subasinghe (Eds.). Use of Chemicals in Aquaculture in Asia. Southeast Asian Fisheries Development Center Aquaculture Department, Tigbauan, Iloilo, Philippines, p. 127-141.

Sulaeman, Suparto, \& Eviati. (2005). Petunjuk Teknis Analisis Kimia Tanah, Tanaman Air, dan Pupuk. Dalam: Prasetyo, B.H. Santoso, D., dan Widowati, L.R. (Eds.). Balai Penelitian Tanah, Bogor, $136 \mathrm{hlm}$.

Sutrisyani \& Rohani, S. (2009). Panduan Praktis Analisis Kualitas Air Payau. Diedit: Rachmansyah, Atmomarsono, M. dan Mustafa, A. Cetakan kedua. Pusat Riset Perikanan Budidaya, Jakarta, $55 \mathrm{hlm}$.

Tarunamulia \& Mustafa, A. (2009). Evaluasi rinci karakteristik dan tingkat kesesuaian lahan tambak di Kecamatan Balusu Kabupaten Barru Provinsi Sulawesi Selatan. Jurnal Riset Akuakultur. Pusat Riset Perikanan Budidaya. Badan Riset Kelautan dan Perikanan, Jakarta, 3(4), 425-438.

Utojo, Mustafa, A., Rachmansyah, \& Hasnawi. (2009). Penentuan lokasi pengembangan budidaya tambak berkelanjutan dengan aplikasi sistem informasi geografis di
Kabupaten Lampung Selatan. Jurnal Riset Akuakultur. Pusat Riset Perikanan Budidaya, Badan Riset Kelautan dan Perikanan, Jakarta, 3(4), 407-423.

Utojo, Mustafa, A., \& Suhaimi, R.A. (2013a). Penentuan kesesuaian budidaya tambak berkelanjutan di Kabupaten Pasuruan, Jawa Timur. Dalam Isnansetyo, A., Husni, A., Djumanto, Rachmawati, N., Widaningroem, R., Rustadi, Suadi, dan Ustadi (Eds.). Prosiding Seminar Nasional Tahunan $X$ Hasil Penelitian Perikanan dan Kelautan Tahun 2013. Jilid 1 Budidaya Perikanan. Bidang Rekayasa Budidaya A, Kode RA1324 (12 hlm). Kerjasama Jurusan Perikanan Fakultas Pertanian UGM dan Balai Besar Litbang Pengelolaan Produk \& Bioteknologi Kelautan \& Perikanan, Jakarta. hlm. 13-24.

Utojo, Paena, M., \& Hasnawi. (2013b). Karakteristik, kesesuaian dan pengelolaan lahan budidaya tambak di Kabupaten Gresik, Jawa Timur. Jurnal Riset Akuakultur. Pusat Penelitian dan Pengembangan Perikanan Budidaya, Badan Penelitian dan Pengembangan Kelautan dan Perikanan, Jakarta, 8(2), 311-324.

Utojo, Pirzan, A.M., \& Mustafa, A. (2012). Kesesuaian lahan budidaya tambak berkelanjutan di Kabupaten Lamongan, Jawa Timur dengan pertimbangan karakteristik dan pengelolaan lahan. Dalam Haryanti, Rachmansyah, Sugama, K., Parenrengi, A., Sudradjat, A., Imron, Sumiarsa, G.S., Azwar, Z.I., dan Kristanto, A.H. (Eds.). Prosiding Seminar Indoaqua-Forum Inovasi Teknologi Akuakultur (FITA) 2012. Pusat Penelitian dan Pengembangan Perikanan Budidaya, Jakarta, hlm. 939-952.

Verschuere, L., Rombaut, G., Sogeloos, P., \& Verstraete, W. (2000). Probiotic bacteria as Biological control agents in aquaculture. Mic. Mol. Biol. Rev., 64(4), 655-671. 